\title{
Assessment of the mineral raw material potential in Denmark - methods and major findings
}

\author{
Jakob Kløve Keiding, Per Kalvig, Claus Ditlefsen, Steen Lomholt and Peter Roll Jakobsen
}

Aggregates and other mineral raw materials are important prerequisites for the continual development of the infrastructure and economic growth of a country. The production of these raw materials in Denmark amounted to $c .4 .5 \mathrm{~m}^{3}$ per capita in 2012, which was $57 \%$ higher than the average in EU and EFTA countries (UEPG 2014). In this perspective, it is essential to locate and assess the Danish mineral resources in order to plan future exploitation, especially in densely populated regions where both spatial competition for landuse and demands for raw materials are high. Here we present the methods used in a recent resource evaluation that for the first time includes Danish resources both on land and at sea and summarises some of the main findings of this analysis.

The importance of availability of mineral raw materials such as sand, gravel, clay and limestone for a society cannot be overestimated: they are prerequisites for the development of the infrastructure and a wide range of products for the industrial sector. The supply of these raw materials is the result of complex value chains, which in turn are based on indicated (see below) and exploited mineral resources from which the raw materials can be processed and turned into commercial materials and products. Globally, sand and gravel account for the largest volume of solid material extracted, with c. 15-25 billion $\mathrm{m}^{3}$ excavated annually, and demand increasing rapidly (GEAS 2014).

The Danish mineral industry includes exploitation of loose aggregate, limestone and chalk, different types of clay, salt and granite, and amounted to $c .35$ million $\mathrm{m}^{3}$ in 2012 of which aggregate alone accounted for c. 90\% (Statistics Denmark 2012a, b). According to a recent forecast, the demand for sand and gravel in 2036 will be c. 40 million $\mathrm{m}^{3}$ (Regionernes Videncenter for Miljø og Ressourcer 2014).

The greater part of the sand and gravel excavated in Denmark is used as aggregate and filler for concrete and other construction purposes. Limestone is mainly used for cement production as industrial filler and as soil conditioner. The clay industry is fairly diversified and uses clay for bricks, insulation stones, membranes and special products such as absorbents and ion-exchange media. Salt is mainly used for de-icing of roads and in the food and chemical industries. About 35000 persons were employed in the primary and secondary sectors of this part of the Danish industry in 2013 with a turnover of about 3500 million DKK (Statistics Denmark 2012a, b).

Exploitation of mineral resources in Denmark takes place at designated sites and the administration is controlled by the Danish Nature Agency for the marine resources and the Danish Regions for the resources on land. There are about 630 onshore sites for excavation of sand, gravel, clay, limestone and granite, and about 100 offshore dredging sites for sand and gravel.

Are there sufficient mineral resources in Denmark to cover the future demand? Sometimes it is postulated that Denmark is endowed with abundant sand and gravel deposits, and aggregates are thus often considered an essentially unlimited resource that will be available for exploitation in the foreseeable future. This is an oversimplified assumption because (1) aggregates cover a diverse group of commodities and not all qualities and types are equally abundant, (2) the distribution of mineral raw materials reflects the local geology and aggregates are geographically unevenly distributed and often have to be transported over considerable distances from the excavation site to the end-use location, and (3) there are many different and often competing landuse interests particularly in a densely populated country like Denmark; exploitation of raw materials does not necessarily have the highest priority.

An assessment of the aggregate resources in terms of their size, type and location - in conjunction with an evaluation of possible areas of conflict with other interests - is crucial for both future resource and landuse planning. On this background the Center for Minerals and Materials (MiMa) conducted the first comprehensive Danish raw material resource assessment comprising both onshore and offshore areas. Additional work on mapping the value chains related to the Danish raw material sector is in progress.

\section{Methods}

This assessment covers the following resources: aggregates (sand, gravel and pebble); limestone and chalk; clay (clay for bricks and tiles; bentonitic clay; diatomite); salt and granite. Aggregates cover a large and diverse group of materials that can be divided into different quality classes according 
to their composition. Traditionally, quality classes applied to marine and terrestrial resources are different. In order to compare the marine and terrestrial inventories this assessment uses the classification used for exploitation of marine deposits. It discriminates between six commercial classes (Fig. 1): Sand 0, Sand 1, Gravel 2, Pebble 3, Filler sand 4 and Sand $\mathrm{X}$ (unspecified quality). It is beyond the scope of this short paper to describe the definition of the various classes and qualities in detail but they reflect difference in grain size, grain size distribution, as well as an assessment of the petrographic composition (i.e. the content of reactive, unstable and porous mineral grains). For further details see Ditlefsen et al. (2015).

This survey is based on data available to the Geological Survey of Denmark and Greenland (GEUS) as per October 2014. The evaluation of land-based resources is based on previous investigations, including mapping of raw materials reported to or conducted by GEUS, as well as new resource assessments conducted by regional authorities within the present extraction areas. Borehole data and geological maps

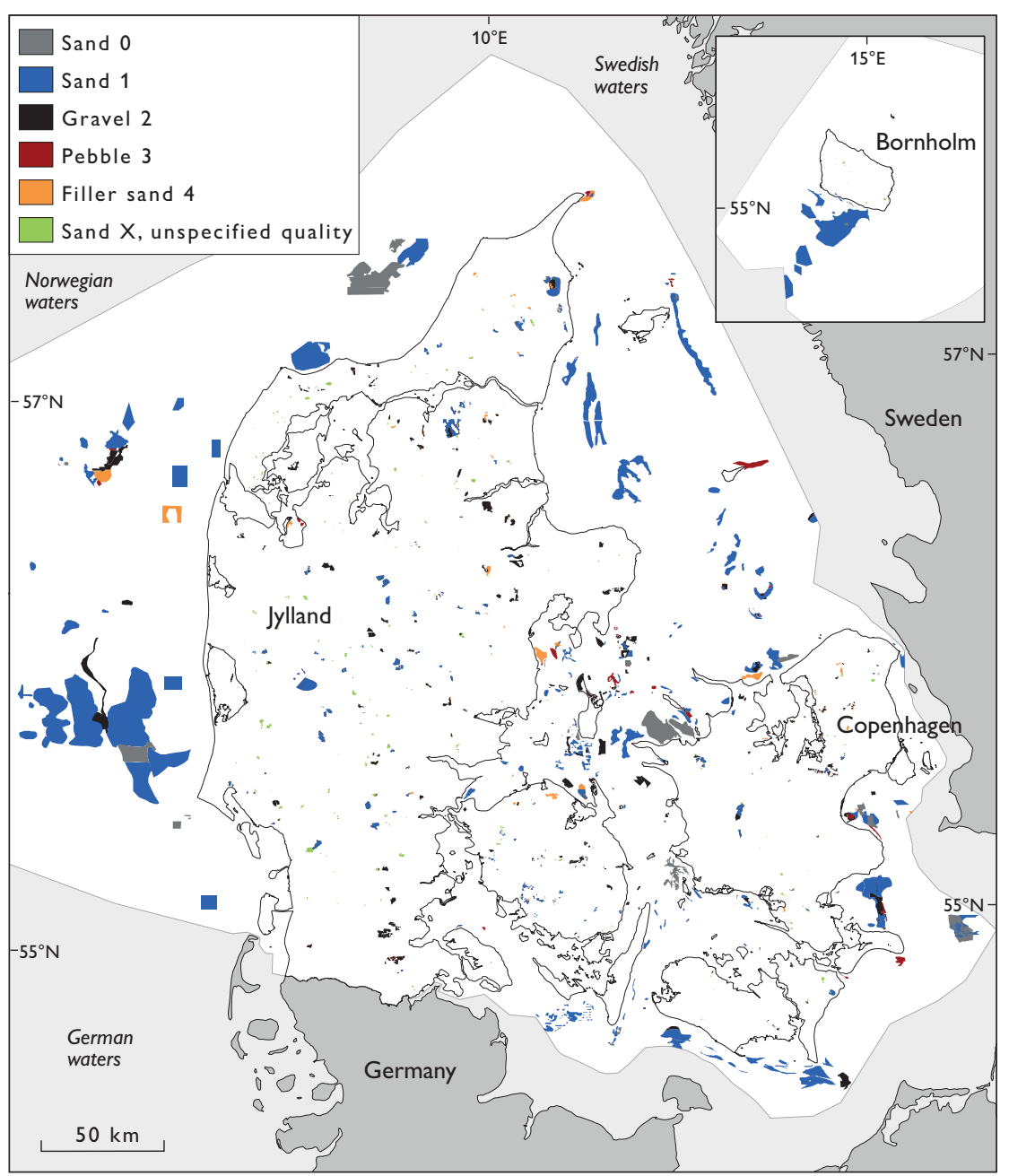

were also used. For the first time we also incorporated data from geophysical surveys conducted for hydrogeological mapping. This allowed us to screen large parts of the terrestrial area for potential undiscovered raw material resources.

The resources addressed in this paper are classified by reliability of the resource data and are divided into three classes, namely measured, indicated and inferred. The criteria for assigning the resources to the different categories were described by Larsen (1994) and Ditlefsen et al. (2015). In essence, the measured resources encompass raw materials that are mapped in detail and have well-known quality parameters. Their characterisation thus has a high degree of certainty $( \pm 20 \%)$. Indicated resources are often based on shallow geophysical surveys and a small number of boreholes and have a lower reliability. Inferred resources are based on geophysical data only, or on relatively sparse geological data, regional-scale mapping, etc. To compile the nation-wide assessment, data from the communes (98 in total) and from 41 marine study areas were amalgamated.

Based on an assessment of the profitable excavation depth, the compilation assesses the volume of raw materials that is available within the top $25 \mathrm{~m}$ below surface, except for salt, which is exploited from deeper-seated salt diapirs and therefore considered to a depth of $500 \mathrm{~m}$ below terrain surface. Based on the same reasoning, we excluded areas with more than 5 $m$ thick layers of soil or other material (overburden) covering the soughtafter resource. When evaluating areas with limestone and chalk, only deposits with less than $10 \mathrm{~m}$ of over-

Fig. 1. Map of Denmark showing the location and areal extent of the different quality classes of aggregate mineral resources used in this assessment. The map illustrates the combined resources of measured and indicated resources. 
Table 1. Summary (in million cubic metres) of calculated gross and net mineral resources in Denmark

\begin{tabular}{|c|c|c|c|c|c|c|}
\hline & Aggregates & Granite & Clay & Chalk and limestone & Salt & Total \\
\hline \multicolumn{7}{|c|}{ Gross resources } \\
\hline Measured & 4603 & 38 & 46 & 293 & 34669 & 39649 \\
\hline Indicated & 10747 & 0 & 68 & 89 & 809230 & 820134 \\
\hline Inferred & 80064 & 3175 & 1190 & 9192 & 489671 & 583292 \\
\hline Sum & 95414 & 3213 & 1304 & 9574 & 1333570 & 1443075 \\
\hline \multicolumn{7}{|c|}{ Net resources } \\
\hline Measured & 4073 & 38 & 46 & 293 & 34669 & 39119 \\
\hline Indicated & 9621 & 0 & 66 & 89 & 809230 & 819006 \\
\hline Inferred & 68888 & 2020 & 1029 & 7048 & 489671 & 568656 \\
\hline Sum & 82582 & 2058 & 1141 & 7430 & 1333570 & 1426781 \\
\hline
\end{tabular}

burden were considered. Data for aggregates were compiled for both marine and terrestrial areas, whereas the remaining raw material groups were only considered on land since at sea they occur under a thick sedimentary cover and are therefore of no interest for exploitation.

All areas with resources were screened with respect to commonly occurring conflicting interests (here referred to as 'no-go' filters). This assessment thus specifies both gross volumes, comprising the total volume of the resources and net volumes, taking into account the effect of 'no-go' filters. The latter are calculated by subtracting volumes underlying areas that are claimed for other landuse from the total mineral resource figures. The 'no-go' filter areas include nature protection areas (Natura 2000 areas, historical monuments, state-protected areas, etc.), major built-up and paved areas, and marine waters less than $6 \mathrm{~m}$ deep where exploitation is prohibited according to present-day jurisdiction, but areas less than $0.01 \mathrm{~km}^{2}$ in size are excluded. Since this is not a full list of areal restrictions, the available area for mineral extraction as well as the extractable net volumes will be smaller due to other local pre-existing priorities.

\section{Results and conclusions}

The mineral assessment presented here covers about $40 \%$ of the Danish marine and terrestrial areas. Possible resource occurrences have been indicated in about $10 \%$ of the surveyed areas. The calculated gross and net mineral resources are summarised in Table 1, and Fig. 1 shows the geographical distribution of the various resource types and qualities of aggregates, the largest commodity group apart from salt.

Salt is the dominant resource in terms of volume for all three classes and comprises $89 \%$ of the measured net resource volumes (Table 1). Salt, however, is a special raw material that

Table 2. Calculated net volumes (million cubic metres) of aggregate resources in Denmark

\begin{tabular}{|c|c|c|c|c|c|c|c|}
\hline & Sand 0 & Sand 1 & Gravel 2 & Pebble 3 & Filler sand 4 & Sand $X^{*}$ & Total \\
\hline \multicolumn{8}{|c|}{ Marine resources } \\
\hline Measured & 184 & 2273 & 207 & 77 & 111 & & 2852 \\
\hline Indicated & 1214 & 6334 & 739 & 135 & 94 & & 8516 \\
\hline Inferred & 497 & 1183 & 106 & 13 & 418 & & 2217 \\
\hline Sum (marine) & 1895 & 9790 & 1052 & 225 & 623 & & 13585 \\
\hline \multicolumn{8}{|c|}{ Terrestrial resources } \\
\hline Measured & & 191 & 656 & 18 & 191 & 165 & 1221 \\
\hline Indicated & & 259 & 554 & 10 & 178 & 104 & 1105 \\
\hline Inferred & & 43 & 96 & 0 & 13 & 66519 & 66671 \\
\hline Sum (land) & & 493 & 1306 & 28 & 382 & 66788 & 68997 \\
\hline \multicolumn{8}{|c|}{ Total assessment } \\
\hline Measured & 184 & 2466 & 863 & 95 & 302 & 165 & 4073 \\
\hline Indicated & 1214 & 6593 & 1293 & 145 & 272 & 104 & 9621 \\
\hline Inferred & 497 & 1226 & 202 & 13 & 431 & 66519 & 68888 \\
\hline Total sum & 1895 & 10283 & 2358 & 253 & 1005 & 66788 & 82582 \\
\hline
\end{tabular}

\footnotetext{
* unspecified quality.
} 
differs from the other mineral resources in several ways: (1) a fundamentally different extraction method is used, (2) it is only found at great depths and (3) and it is regulated by the Danish Subsoil Act (Undergrundsloven) in contrast to the other resources assessed here that are regulated by the Raw Materials Act (Råstofloven).

On a national scale, the measured resources of aggregates account for $c$. $10 \%$ of the registered mineral resources, followed by chalk and limestone (c. 1\%; whereas the volumes of clay and granite account for less than $1 \%$ ). For all the five types of raw material considered, the volume of the inferred resource class is enormous (Table 1). However, only minor fractions of these volumes will be available for exploitation due to conflicting landuse interests.

Aggregates mainly come from either glaciofluvial deposits or from Late- and Postglacial marine deposits. Marine deposits are more mature than glaciofluvial deposits and usually contain smaller amounts of reactive grains that are harmful to constructions. In addition, older deltaic and fluvial deposits of pure quartz sand are found in central Jylland and on and around the island of Bornholm. Granites in Denmark are confined to Bornholm where they are part of the Precambrian basement that is exposed or just covered by thin Quaternary deposits on the northern two thirds of the island. Clay is mainly of glaciolacustrine or marine origin, while limestone and chalk are marine formations of Cretaceous and early Cenozoic age. The salt resources in Denmark are Permian in age and related to evaporates from the Zechstein basin. Most salt deposits are found at more than $3 \mathrm{~km}$ depth, and are of no economic interest. Locally, however, the salt has been mobilised and is found in shallower diapirs at depths of 200-300 m.

Sand $X$ (unspecified quality) is the largest class in the aggregate group and comprises $c .81 \%$ of the total volume of all aggregates (Table 2). The resources in this class are currently based only on geophysical screening and require a more thorough characterisation with respect to grain size, grain-size distribution, petrographic composition as well as better constraints on the spatial distribution. However, this class offers unique possibilities to focus future exploration for aggregates in relevant areas. Sand 1, Gravel 2, Pebble 3 and Filler sand 4 are the present commercial classes. These qualities are not equally distributed, hence about $95 \%$ of the Sand 1 resources are located offshore, and about $88 \%$ of the Pebble 3 resources are found onshore (measured resources, Table 2). Within the onshore areas, the sand and gravel resources are unevenly dis- tributed, for example, very limited proven gravel resources are indicated close to the city of Copenhagen. These observations are important for long-term planning of how to exploit the known resources. There is an up to $19 \%$ difference between distribution of gross and net deposits for the various raw material qualities when looking at measured and indicated resource classes. The largest changes are seen for Pebble 3 (19\%), Filler sand 4 (18\%), Sand 1 (10\%) and Sand 0 (7\%). The effect of the 'no-go' filters is generally rather limited for most of the commodities and raw material classes due to a few very large deposits. This is in particular the case when including the inferred resources, which overshadows localscale restrictions, and thus in places the filters have a major impact on the resulting resource figures. Also, a number of other constraints may be considered prior to designation of a resource resulting in substantial lower net resource figures.

This survey shows that Denmark is endowed with enormous mineral resources of aggregates, clay and special clay, chalk and limestone, and salt and granite. However, to what extent these resources will be available as raw materials for the mineral industry is uncertain since it depends on local landuse and restrictions. Finally, this assessment shows that both off- and onshore aggregate deposits will have to be considered in order to secure the supply of all quality classes.

\section{References}

Ditlefsen, C.B., Lomholt, S., Skar, S., Jakobsen, P.R., Kallesøe, A.J., Keiding, J.K. \& Kalvig, P. 2015: Danske mineralske råstofressourcer. Kvantitativ analyse baseret på geologiske og geofysiske data. MiMa Report 2015/1, 61 pp. Copenhagen: Geological Survey of Denmark and Greenland.

GEAS (Global Environmental Alert Service) 2014: Sand, rarer than one thinks. www.unep.org/pdf/UNEP_GEAS_March_2014.pdf

Larsen, B. 1994: Material sammensætningen i submarine råstofforekomster - et metodestudium. DGU Kunderapport 91, 51 pp. København: Danmarks Geologiske Undersøgelse.

Regionernes Videncenter for Miljø og Ressourcer 2014: Fremskrivning af råstofforbruget for 2013-2036. Region Syddanmark. Råstoffer 4, 27 pp.

Statistics Denmark 2012a: Statistikbank - råstoffer indvundet fra havet. http://www.statistikbanken.dk/statbank5a/SelectVarVal/Define. asp?Maintable $=$ RST3\& PLanguage $=0$

Statistics Denmark 2012b: Statistikbank - råstoffer indvundet på land. http://www.statistikbanken.dk/statbank5a/SelectVarVal/Define. asp? Maintable $=$ RST01\&PLanguage $=0$

UEPG (Union Européenne des Producteurs de Granulats) 2014: European Aggregates Association. A sustainable industry for a sustainable Europe. Annual Review 2013-2014. http://www.uepg.eu/uploads/ Modules/Publications/uepg-ar2013-2014_v28.pdf

\footnotetext{
Authors' address

Geological Survey of Denmark and Greenland, Øster Voldgade 10, DK-1350 Copenhagen K, Denmark; E-mail:jkk@geus.dk
} 